\title{
KOORDINASI PERENCANAAN PENGEMBANGAN WILAYAH AGROPOLITAN DALAM PEMBANGUNAN EKONOMI MASYARAKAT (Studi di Badan Perencanaan Pembangunan Daerah Kabupaten Sumenep)
}

\author{
Drs. Yayak Nurwahyudi ${ }^{1}$ \\ Dosen Fakultas Ilmu Sosial dan Ilmu Politik Universitas Wiraraja \\ Dra. Irma Irawati $\mathrm{P}^{2}$ \\ Dosen Fakultas Ilmu Sosial dan Ilmu Politik Universitas Wiraraja
}

Gisca Dwi Cahyaningtyas ${ }^{3}$

\begin{abstract}
Abstrak
Kabupaten Sumenep sebagai daerah yang sebagian besar penduduknya berprofesi di bidang Agrikultur. Kebijakan pembangunan agropolitan memberikan harapan besar terhadap bidang agrikultur ini. Berdasarkan pengembangan wilayah yang direncanakan oleh RPJMD Badan Perencanaan Pembangunan Daerah Kabupaten Sumenep, harapan besar pemerintah tersebut seakan-akan sulit direalisasikan sebagai akibat dari persoalan yang masih menerpa proses implementasi pembangunan agropolitan di Kabupaten Sumenep, karena protes warga yang kurang dilibatkan dalam perencaanaan pembangunan agropolitan tersebut karena kurangnya koordinasi Pemerintah Kabupaten Sumenep dengan masyarakat terkait lokasi pasar agropolitan, Untuk dapat tercapainya perencanaan yang efisisensi, efektifitas dan produktifitas, maka perlu dilakukan koordinasi Badan Perencanaan Pembangunan Daerah Kabupaten Sumenep dengan masyarakat.

Penelitian ini menggunakan teori koordinasi yang menyatakan bahwa koordinasi merupakan kegiatan pengaturan usaha sekelompok orang secara terarah dan teratur untuk menciptakan kesatuan gerak/tindakan dalam usaha mencapai tujuan organisasi serta untuk mendapatkan kesalarasan gerak, keselarasan aktivitas dan keselarasan tugas antar satuan organisasi yang ada di dalam organisasi, dengan demikian tujuan organisasi akan tercapai secara efektif apabila semua orang, semua pejabat, dan semua unit/satuan organisasi serta semua sumber daya diselaraskan dengan tujuan organisasi. Hasil penelitian menunjukkan bahwa analisa penelitian dan pembahasan pada penelitian ini dapat diketahui bahwasannya pemerintah yaitu Bappeda telah berperan sebagai koordinator pengembangan wilayah agropolitan dalam pembangunan ekonomi masyarakat. Adapun koordinasi tersebut telah sesuai sebagaimana fokus dalam penelitian ini yakni tentang bentuk perencanaan melalui pendekatan koordinasi.
\end{abstract}

Kata kunci : Agropolitan, koordinasi, BAPEDDA 


\section{Pendahuluan}

Indonesia merupakan Negara agraris yang memang seharusnya mengandalkan sektor pertanian sebagai sumber pembangunan ekonomi maupun sebagai penopang pembangunan. Dikatakan Negara agraris, karena $75 \%$ penduduknya hidup di pedesaan dan $25 \%$ menggantungkan hidup dari sektor pertanian

(http://epublikasi.pertanian.go.id, 03 Desember 2018). Dalam hal ini sektor pertanian dapat menopang pembangunan yaitu dengan sektor pertanian yang ada maka pembangunan ekonomi masyarakat dapat meningkat khususnya pada masyarakat pedesaan, karena dengan adanya sektor pertanian melalui kontribusi pertanian dalam pembangunan ekonomi yaitu; pertanian sebagai penyerap tenaga kerja, kontribusi terhadap pendapatan, kontribusi dalam penyediaan pangan, kontribusi sebagai penyedia bahan baku, kontribusi dalam bentuk kapital, Todaro dalam Ernan Rustiadi dkk (2011:120).

Dalam banyak kegiatan yang bertujuan untuk pembangunan ekonomi masyarakat di pedesaan, sudah pasti ada banyak faktor yang ikut berpengaruh di dalamnya. Secara lebih rinci, pembangunan ekonomi pedesaan ialah suatu potensi yang ada pada suatu desa dan dapat dimanfaatkan dengan baik untuk kesejahteraan bersama bagi masyarakat desa. Pemanfaatan potensi dari pedesaan tersebut jika dilakukan dengan cermat dan konsisten dapat sertamerta menaikkan kondisi perekonomian dan kesejahteraan masyarakat desa secara bersama-sama, salah satunya yaitu dengan melalui adanya pengembangan wilayah agropolitan. Wilayah agropolitan adalah wilayah agribisnis atau sentra produksi pertanian terpilih, dimana pada wilayah tersebut terdapat wilayah pertanian (agropolis) yang merupakan pusat pelayanan agribisnis yang melayani, mendorong, dan menopang pembangunan ekonomi masyarakat pedesaan.

Kabupaten Sumenep dalam pengembangan wilayah agropolitan untuk pembangunan ekonomi masyarakat pedesaan sangat penting, karena sebagian besar anggota masyarakat Kabupaten Sumenep menggantungkan hidupnya pada sektor pertanian, hal ini terlihat dari nilai Produk Domestik Regional Bruto (PDRB) Kabupaten Sumenep yang menunjukkan bahwa sektor pertanian merupakan sektor penyumbang ekonomi terbesar dibandingkan dengan sektor lainnya, Selama kurun waktu 5 tahun terakhir, peningkatan PDRB atas dasar harga berlaku rata-rata bertambah sekitar Rp. 3,31 trilyun, sedangkan PDRB atas dasar harga konstan pergerakannya ratarata sekitar Rp. 1,59 trilyun, kenaikan PDRB ini membuat Sumenep bergeser ke urutan 13 yang sebelumnya urutan 20 dari 
38 Kabupaten/Kota se Jawa Timur (https://sumenepkab.bps.go.id/, November 2018).

Kondisi ini merupakan alasan mengapa pihak Provinsi Jawa Timur menetapkan bahwa Kabupaten Sumenep sangat potensial untuk dijadikan wilayah agropolitan, yaitu wilayah/kawasan yang berbasis pertanian berkelanjutan sehingga sektor pertanian dapat terus dijadikan sektor unggulan di Kabupaten Sumenep.

Pembangunan agropolitan bagi masyarakat Kabupaten Sumenep memiliki tujuan yang luhur, namun seiring dengan pelaksanaan pembangunan tersebut masih butuh banyak penyesuaian yang terkait dengan koordinasi antara pemerintah dan masyarakat. Sehingga nantinya kebijakan ini dapat terlaksana optimal dan sesuai dengan target yang ingin dicapai.

Berdasarkan pengembangan wilayah yang direncanakan oleh RPJMD Badan Perencanaan Pembangunan Daerah Kabupaten Sumenep, harapan besar pemerintah tersebut seakan-akan sulit direalisasikan sebagai akibat dari persoalan yang masih menerpa proses implementasi pembangunan agropolitan di Kabupaten Sumenep, karena protes warga yang kurang dilibatkan dalam perencaanaan pembangunan agropolitan tersebut maka pembangunan wilayah agropolitan ini sampai dengan saat ini masih menuai protes warga setempat.
Koordinasi dalam proses perencanaan pembangunan merupakan tugas dan fungsinya Badan Perencanaan Pembagunan Daerah sebagaimana tertuang dalam Permendagri No 86 Tahun 2017 Pasal 1 bahwa Badan Perencanaan Pembangunan Daerah adalah Perangkat Daerah yang melaksanakan tugas dan mengoordinasikan penyusunan, pengendalian, dan evaluasi pelaksanaan rencana pembangunan Daerah baik dengan instansi, dinas daerah, kecamatan, dan badan-badan pemerintahan lainnya dan masyarakat demi mewujudkan tujuan pembangunan yang telah ditetapkan sebelumnya.

\section{Rumusan Masalah}

Berdasarkan latar belakang diatas, maka rumusan masalah dalam penelitian ini adalah bagaimana Koordinasi Badan Perencanaan Pembagunan Daerah (BAPPEDA) tentang Perencanaan Pengembangan Wilayah Agropolitan Dalam Pembangunan Ekonomi Masyarakat Kabupaten Sumenep?

\section{Teori Koordinasi}

Koordinasi berasal dari kata coordination, co dan ordinare yang berarti to regulate. Dari pendekatan empirik yang dikaitkan dengan etimologi, koordinasi diartikan sebagai kegiatan yang dilakukan oleh berbagai pihak yang sederajat (equal in rank or order, of the 
same rank or order, not subordinate) untuk saling memberi informasi dan mengatur (menyepakati) hal tertentu (Ndraha, 2003:290).

Menurut Bappenas (2008), Proses perencanaan melalui pendekatan koordinasi terdiri dari:

a. Perencanaan makro

Perencanaan pembangunan makro adalah perencanaan pembangunan nasional dalam skala makro atau menyeluruh. Dalam perencanaan makro ini dikaji berapa pesat pertumbuhan ekonomi dapat dan akan direncanakan, berapa besar tabungan masyarakat dan pemerintah akan tumbuh, bagaimana proyeksinya, dan hal-hal lainnya secara makro dan menyeluruh. Kajian ini dilakukan untuk menentukan tujuan dan sasaran yang mungkin dicapai dalam jangka waktu rencana, dengan memperhitungkan berbagai variabel ekonomi mikro. Perencanaan makro ini dilakukan dengan melihat dan memperhitungkan secara cermat keterkaitannya dengan perencanaan sektoral dan regional.

b. Perencanaan sektoral

Perencanaan sektoral adalah perencanaan yang dilakukan dengan pendekatan berdasarkan sektor. Yang dimaksud dengan sektor adalah kumpulan dari kegiatan-kegiatan atau program yang mempunyai persamaan ciri-ciri serta tujuannya. Pembagian menurut klasifikasi fungsional seperti sektor, maksudnya untuk mempermudah perhitunganperhitungan dalam mencapai sasaran makro. Sektor-sektor ini kecuali mempunyai ciri-ciri yang berbeda satu sama lain, juga mempunyai daya dorong yang berbeda dalam mengantisipasi investasi yang dilakukan pada masingmasing sektor. Meskipun pendekatan ini menentukan kegiatan tertentu, oleh instansi tertentu, di lokasi tertentu, faktor lokasi pada dasarnya dipandang sebagai tempat atau lokasi kegiatan saja. Pendekatan ini berbeda dengan pendekatan perencanaan lainnya yang terutama bertumpu pada lokasi kegiatan.

c. Perencanaan regional

Perencanaan regional menitikberatkan pada aspek lokasi di mana kegiatan dilakukan. Pemerintah daerah mempunyai kepentingan yang berbeda dengan instansi-instansi di pusat dalam melihat aspek ruang di suatu daerah. Departemen/lembaga pusat dengan visi atau kepentingan yang bertitik berat sektoral melihat "lokasi untuk kegiatan", sedangkan pemerintah daerah dengan titik berat pendekatan pembangunan regional (wilayah/daerah) melihat "kegiatan untuk lokasi". Kedua pola pikir itu bisa saja menghasilkan hal yang sama, namun sangat mungkin menghasilkan usulan yang berbeda. Pemerintah daerah dalam merencanakan pembangunan daerah mengupayakan 
pendayagunaan ruang di daerahnya, mengisinya dengan berbagai kegiatan (jadi sektoral) sedemikian rupa sehingga menghasilkan alternatif pembangunan yang terbaik bagi daerah tersebut. Pilihan daerah terhadap alternatif yang tersedia dapat menghasilkan pertumbuhan yang tidak optimal dari sudut pandang sektor yang melihat kepentingan nasional secara sektoral. Berbagai pendekatan tersebut perlu dipadukan dalam perencanaan pembangunan nasional, yang terdiri dari pembangunan sektor-sektor di berbagai daerah, dan pembangunan daerah/wilayah yang bertumpu pada sektor-sektor.

\section{d. Perencanaan mikro}

Perencanaan mikro adalah perencanaan skala rinci dalam perencanaan tahunan, yang merupakan penjabaran rencana-rencana baik makro, sektoral, maupun regional ke dalam susunan proyek-proyek dan kegiatankegiatan dengan berbagai dokumen perencanaan dan penganggarannya. Secara operasional perencanaan mikro ini antara lain tergambar dalam Daftar Isian Proyek (DIP), Petunjuk Operasional (PO), dan rancangan kegiatan. Perencanaan ini merupakan unsur yang sangat penting, karena pada dasarnya pencapaian tujuan dan sasaran pembangunan, baik untuk PJP II maupun yang tertulis dalam Repelita VI, seluruhnya diandalkan pada implementasi dari rencana-rencana di tingkat mikro. Efektivitas dan efisiensi yang menjadi masalah nasional sehari-hari dapat ditelusuri penanganannya dalam perencanaan dan pelaksanaan rencana di tingkat

mikro.

Koordinasi Perencanaan

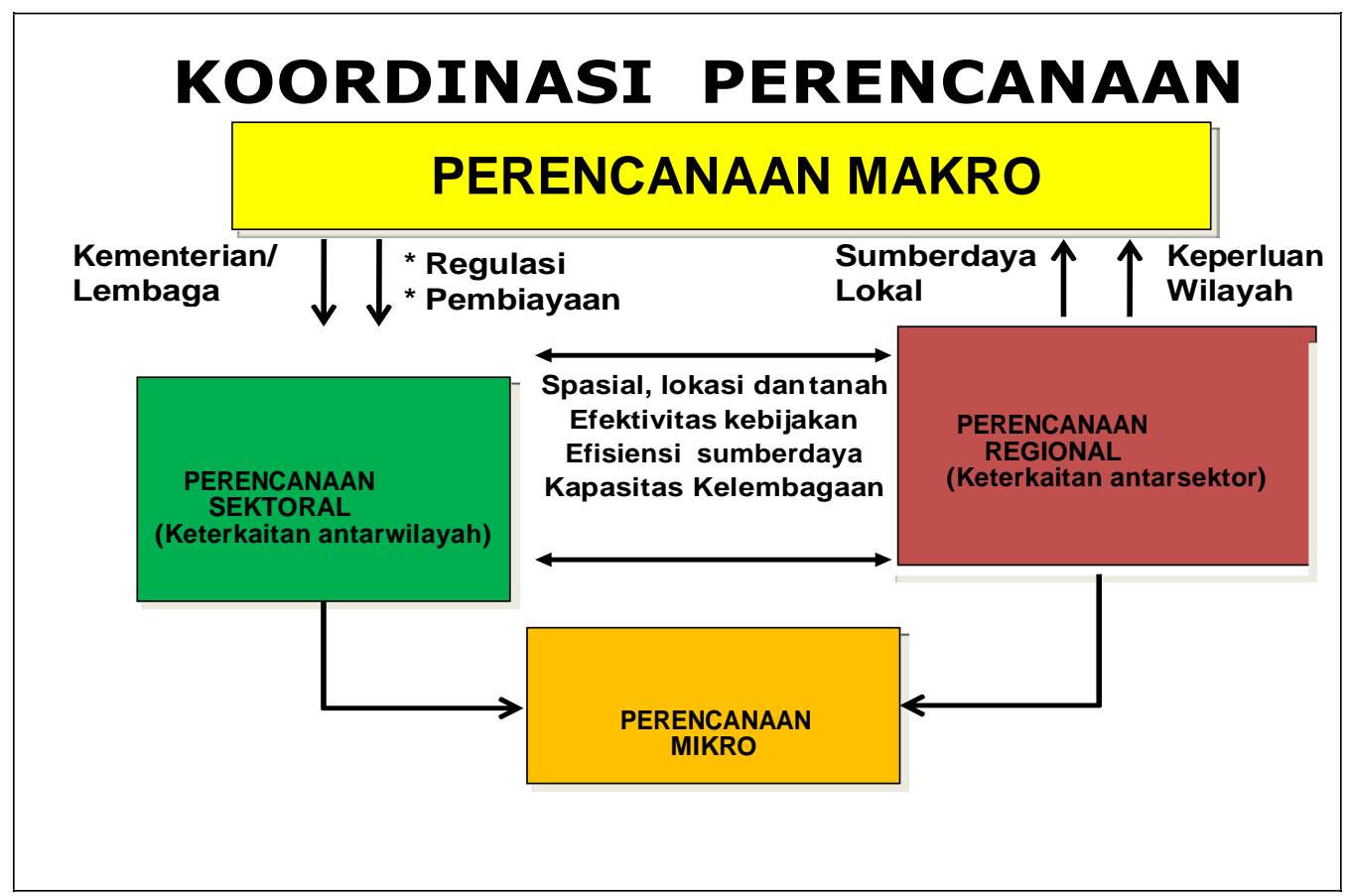




\section{Agropolitan}

Agropolitan menurut Ernan Rustiadi dkk (2011:329) merupakan sebuah pendekatan pengembangan suatu wilayah pertanian perdesaan yang mampu memberikan berbagai pelayanan untuk memenuhi kebutuhan masyarakat di wilayah produksi pertanian di sekitarnya, baik pelayanan yang berhubungan dengan sarana produksi, jasa distribusi, maupun pelayanan sosial ekonomi lainnya sehingga masyarakat setempat tidak harus menuju kota untuk menjual hasil produksi pertaniannya.

Ernan Rustiadi dkk (2011:329) mengatakan terdapat dua hal yang menyebabkan interaksi desa-kota menjadi suatu hal yang merugikan bagi perkembangan desa yaitu: (1) terbatasnya distribusi fasilitas dan pelayanan diantara wilayah perdesaan; dan (2) terbatasnya keterkaitan antar lokasi menengah di wilayah perdesaan.

UU No. 26 Tahun 2007 tentang Penataan Ruang disebutkan bahwa wilayah agropolitan adalah wilayahwilayah yang terdiri atas satu atau lebih pusat kegiatan pada wilayah perdesaan sebagai system produksi pertanian dan pengelolaan sumber daya alam tertentu yang ditunjukkan oleh adanya keterkaitan fungsional dan hierarki keruangan satuan system permukiman dan sistem agrobisnis.

\section{Metode Penelitian}

Penelitian ini menggunakan metode deskriptif kualitatif karena dalam penelitian ini mendeskriptifkan keadaan yang terjadi pada saat sekarang secara sistematis dan faktual. Pengertian penelitian kualitatif dapat diartikan sebagai penelitian yang menghasilkan data deskriptif mengenai kata-kata lisan maupun tertulis, dan tingkah laku yang dapat diamati dari orang-orang yang dapat diteliti. (Taylor \& Bogdan dalam Suyanto, 2011:166).

Penelitian ini dilakukan pada Badan Perencanaan Pembangunan Daerah Kabupaten Sumenep. Alasan pemilihan lokasi penelitian dilakukan dengan pertimbangan bahwa Koordinasi dalam proses perencanaan pembangunan merupakan tugas dan fungsinya Badan Perencanaan Pembagunan Daerah Kabupaten Sumenep. Menurut Sjafrizal (2015), Perencanaan menurut dimensi pendekatan koordinasi perencanaan pembangunan terdiri dari 3 , sebagaimana yang ditetapkan sebagai fokus penelitian Koordinasi Perencanaan Pengembangan Wilayah Agropolitan Dalam Pembangunan Ekonomi Masyarakat sebagai berikut:

1) Perencanaan Makro 
Dalam perencanaan makro yang akan diteliti yaitu pertumbuhan ekonomi masyarakat wilayah agropolitan khususnya yang ada di Kecamatan Rubaru.

2) Perencanaan Sektoral

Perencanaan sektoral untuk mengetahui peran Badan Perencanaan Pembangunan Daerah Kabupaten Sumenep dan sektor apa saja yang terlibat dalam pembangunan pasar agropolitan serta untuk mengetahui kondisi umum terkait potensi pertanian yang dimiliki Kecamatan Rubaru sehingga ditetapkan sebagai wilayah agropolitan.

3) Perencanaan Regional

Perencanaan regional untuk meneliti koordinasi Badan Perencanaan Pembangunan Daerah Kabupaten Sumenep dalam menyusun strategi, kebijakan dan program pembangunan dengan memanfaatkan potensi wilayah Kecamatan Rubaru dan keuntungan lokasi yang terdapat di daerah pengembangan wilayah agropolitan yang terletak di Kecamatan Rubaru.

Dalam penelitian ini yang menjadi lokasi penelitian adalah Badan Perencanaan Pembangunan Daerah Kabupaten Sumenep.
Untuk teknik pengumpulan data digunakan dalam penelitian ini ialah dengan teknik observasi dimana mengamati fenomena yang menjadi titik obyek dalam fokus penelitian. Melalui observasi harapannya peneliti akan mengetahui secara jelas bagaimana koordinasi BAPPEDA Kabupaten Sumenep mengenai pengembangan wilayah agropolitan dalam pembangunan ekonomi masyarakat. Teknik kedua yaitu wawancara, melalui wawancara peneliti dapat memperoleh keterangan dalam menggali berbagai informasi mengenai konteks sub bahasan yang akan dikaji dalam penelitian. Serta teknik ketiga yaitu dokumentasi, dalam penelitian ini dokumentasi dilakukan dengan mengamati, memahami, maupun meminta isi dari berbagai dokumen-dokumen relevan yang disajikan oleh BAPPEDA Kabupaten Sumenep dalam mendukung validitas data yang peneliti teliti.

\section{Hasil Penelitian}

Hasil penelitian ini dihasilkan oleh peneliti melalui wawancara, observasi, dan dokumentasi di Badan Perencanaan Pembangunan Kabupaten Sumenep. Berdasarkan hasil analisa penelitian yang telah dilakukan koordinasi perencanaan pengembangan wilayah agropolitan dalam pembangunan ekonomi masyarakat studi Badan Perencanaan Pembangunan Daerah Kabupaten Sumenep, maka pada 
bagian ini penulis akan melakukan pembahasan yang akan dikaji secara teoritik berdasarkan teori koordinasi perencanaan pembangunan menurut Sjafrizal 2015, dengan memfokuskan pada pada tiga perencanaan yaitu perencanaan Makro, Perencanaan Sektoral dan Perancanaan Regional.

1.Perencanaan Makro
Perencanaan makro yang
dikoordinasikan Bappeda yaitu
koordinasi untuk meningkatkan
pembangunan ekonomi di wilayah
agropolitan yang pertama itu dengan
membentuk SK tim pokja yang dimana
Bappeda menjadi ketua tim koordinator
sebagai koordinator dalam pelaksanaan
pengembangan wilayah agropolitan, tim
pokja disini terdiri dari instansi-instansi
yang terlibat dalam rapat koordinasi,
kemudian pengembangan kelembagaan
masyarakat melalui pemberdayaan
kelompok tani, gabungan kelompok tani
dan koperasi wanita, yang ketiga
mengalokasikan anggaran dalam rangka
mendukung kawasan agropolitan yaitu
antara lain untuk mengembangkan sarana
dan prasarananya serta fasilitas penduduk
lainnya. Kemudian mengoptimalkan
realisasi kegiatan program pengembangan
wilayah agropolitan, merubah
pengelolahan lahan pertanian yang
semula bersifat tradisional menjadi lebih
modern, efektif dan tepat guna.

Sebagaimana yang dimaksud bahwa perencanaan pengembangan wilayah agropolitan untuk pembangunan ekonomi masyarakat, Bappeda memiliki tugas sebagai koordinator. Yang dimana koordinasi akan dapat dijalankan dengan cara mengangkat koordinator atau membuat tim kelompok kerja terlebih dahulu untuk menjembatani hubungan kerja pemerintah dalam pembangunan ekonomi itu sendiri (Wursanto, 2005:254).

Namun pada kenyataannya dalam koordinasi perencanaan makro bersama instansi dan masyarakat kecamatan Rubaru, Bappeda disini masih belum melakukan koordinasi secara baik terbukti dengan yang dikatakan masyarakat daerah wilayah agropolitan yaitu kecamatan Rubaru bahwa mereka kurang dilibatkan dalam hal perencanaan wilayah agropolitan ini, mereka hanya dilibatkan dalam satu kali pertemuan saja kemudian kendalanya dari sisi pendanaan yang kurang memadai. Padahal masyarakat daerah Kecamatan Rubaru sangat berharap dengan adanya rencana pengembangan wilayah agropolitan ini perekonomian mereka dapat meningkat. Maka dari itu tidak sepaham dengan yang dikatakan Ernan Rustiadi dkk, (2011) bahwa Agropolitan merupakan sebuah pendekatan pengembangan suatu wilayah pertanian perdesaan yang mampu memberikan berbagai pelayanan untuk 
memenuhi kebutuhan masyarakat di wilayah produksi pertanian di sekitarnya, baik pelayanan yang berhubungan dengan sarana produksi, jasa distribusi, maupun pelayanan sosial ekonomi lainnya sehingga masyarakat setempat tidak harus menuju kota untuk menjual hasil produksi pertaniannya.

Pengembangan wilayah agropolitan di Kecamatan Rubaru sangat erat kaitannya dengan pembangunan ekonomi masyarakat disana, karena tujuan utama dari kegiatan ini ialah untuk dapat mengembangkan suatu wilayah pertanian di pedesaan sehingga mampu mewujudkan perekonomian masyarakat Rubaru melalui peningkatan pendapatan para pelaku ekonomi yang ada di dalamnya. Sebagaimana yang disampaikan oleh (Siagian, 2012:81), bahwasannya pembangunan ekonomi harus dipandang paling sedikit dari dua sisi. Sisi yang pertama berkaitan dengan pemenuhan kebutuhan masyarakat, sisi kedua menyangkut pertumbuhan dan pengembangan agrobisnis yang menghasilkan berbagai komoditi pertanian.

Koordinasi lainnya yaitu pihak Bappeda melakukan sosialisasi kepada masyarakat setempat bahwa di Kecamatan Rubaru itu akan dibentuk suatu wilayah agropolitan, yang dimana agropolitan itu artinya kota pertanian, yang dimulai dari awalnya peningkatan
SDM atau pemberdayaan masyarakat untuk bisa mengembangkan wilayah itu dan meningkatkan perekonomian masyarakat di wilayah itu. Koordinasi itu dilakukan bahwa untuk tercapainya suatu program harus ada kesepahaman antara Bappeda sebagai pemerintah dan masyarakat sebagai unsur yang melaksanakan, maka dari itu harus terus dilakukan sosialisasi, motivasi, sehingga apa yang Bappeda rencanakan dapat berjalan dengan baik. Namun pada kenyataannya menurut warga daerah agropolitan koordinasi memang sudah ada dari pihak bappeda, dan sempat ada sosialisasi dari pihak dinas pertanian terkait pertanian di wilayah agropolitan tetapi untuk yang lokasi pasar agropolitan warga kurang dilibatkan dalam perencanaannya. Sebagaimana yang disampaikan Marbu'ah selaku petani bahwa mereka sudah sangat senang karena daerahnya dijadikan wilayah agropolitan tetapi disisi lain mereka kecewa karena dalam pembangunan pasar agropolitan bukan ditempat yang diharapkan masyarakat. Sebagaimana yang disampaikan oleh Awaluddin Djamin dalam Hasibuan (2011:86) bahwa sebagai suatu usaha kerja sama antara badan, instansi dan masyarakat dalam pelaksanaan tugas-tugas tertentu, sehingga terdapat saling mengisi, saling membantu dan saling melengkapi. Dengan demikian koordinasi dapat 
diartikan sebagai suatu usaha yang mampu menyelaraskan pelaksanaan tugas maupun kegiatan dalam suatu organisasi.

2. Perencanaan Sektoral Berkaitan dengan koordinasi perencanaan sektoral maka Bappeda melakukan koordinasi perencanaan sektoral yang dilakukan oleh Bappeda yaitu berkoordinasi bersama dengan Dinas Pertanian Tanaman Pangan Hortikultura Dan Perkebunan, Dinas Koperasi dan Usaha Mikro, Dinas Perindustrian Dan Perdagangan, serta GAPOKTAN (Gabungan Kelompok Tani) dan setiap instansi sudah memiliki peranannya masing-masing. Seperti Dinas Perindustrian Dan Perdagangan mendapatkan tugas mengoptimalkan industri pertanian dan memberikan bantuan peralatan dan permodalan untuk petani dan juga pengadaan alat-alat modern agar mempermudah petani dalam mengolah tanaman serta membangun pasar agropolitan, selanjutnya Dinas Pertanian Tanaman Pangan Hortikultura Dan Perkebunan mendapatkan pembagian tugas seperti memberikan informasi benih terbaru serta harga yang terjangkau, pengoptimalan kios untuk penyediaan benih tanaman, mendirikan balai benih di wilayah agropolitan, dan melakukan sosialisasi peningkatan kemampuan petani dalam memproduksi benih tanaman/bibit yang berkwalitas, kemudian Dinas Koperasi dan Usaha Mikro mendapatkan tugas menyediakan benih tanaman pada Koperasi Unit Desa (KUD) dan GAPOKTAN (Gabungan Kelompok Tani) di wilayah Rubaru untuk mengembangkan wilayah agropolitan. Sebagaimana yang dimaksud oleh Mudrajat, (2004:113) bahwa perencanaan pengembangan wilayah agropolitan untuk pembangunan ekonomi masyarakat, pemerintah memiliki peran sebagai koordinator. Peran koordinator pemerintah dalam pembangunan ekonomi itu sendiri ialah untuk menyusun tujuan maupun strategi ekonomi dengan melibatkan lembaga pemerintah lainnya, badan usaha maupun kelompokkelompok masyarakat. Hal ini sebagaimana pula yang disampaikan oleh Adisasmita (2013:125) bahwa koordinasi berarti masing-masing sektor (instansi) menyusun rencana pembangunannya sendiri, yang kemudian dikoordinasikan dengan sektor-sektor (instansi) yang terkait serta masyarakat secara bersamasama, karena dalam pelaksanaan kegiatan pembangunan terdapat keterhubungan dan ketergantungan agar dapat dicapai tujuan yang optimal.

Adapun kendala dalam koordinasi perencanaan sektoral ini adalah kesulitan dalam menemukan jenis yang akan dijadikan produk unggulan agropolitan Sumenep, namun setelah menemukan bahwa bawang merah yang akan 
dijadikan produk unggulan, maka Bappeda sudah mampu memberi benih bawang merah kepada masyarakat agar pengembangan wilayah agropolitan lebih cepat lagi serta kendalanya terdapat pada keinginan yang bermacam-macam dari setiap instansi dan masyarakat. Dan kenyataan yang di dapat di lapangan, hubungan koordinasi antar instansi pengelola wilayah agropolitan masih kurang efektif. Ini dapat diketahui dari hasil wawancara penulis dengan Kepala Badan Perencanaan Pembangunan Daerah Kabupaten Sumenep dimana dalam melakukan koordinasi agropolitan masih di taraf 40\%, Hal ini disebabkan kurangnya komitmen terhadap penyelesaian wilayah agropolitan. Hal ini sebagaimana yang disampaikan Arifin dalam Manila (2012:107) bahwasannya koordinasi bukan hanya bekerjasama, melainkan juga integrasi dan singkronisasi yang mengharuskan penyelarasan setiap unsur-unsur yang terlibat dan penentu waktu kegiatan disamping penyesuaian perencana, dan keharusan adanya komunikasi yang teratur diantara semua pelaku yang bersangkutan demi mewujudkan komitmen yang dibuat sebagai suatu peraturan pelaksanaan.

\section{Perencanaan Regional}

Perencanaan regional merupakan perencanaan pengembangan wilayah agropolitan, hal pertama kali yang dilakukan oleh Bappeda ialah melihat lokasinya terlebih dahulu di Kecamatan Rubaru dari topografinya, potensinya apa saja, hasil pertaniannya seperti apa kemudian sarana pra sarana lokasinya. Hal itu dilakukan bertujuan agar hasil yang diperoleh dapat meningkatkan perekonomian masyarakat Rubaru. Sebagaimana menurut (Ernan Rustiadi dkk, 2011) bahwa pengembangan agropolitan ditujukan untuk meningkatkan produksi pertanian yang ada dan penjualan hasil-hasil pertanian, dan mendorong aktivitas ekonomi dari pusat agropolitan.

Berdasarkan data Data Potensi Pertanian Kecamatan Rubaru, Data Potensi Perkebunan Kecamatan Rubaru, Data Potensi Buah dan Sayur Kecamatan Rubaru Pemerintah selanjutnya melakukan koordinasi perencanaan regional ke masyarakat daerah Rubaru bahwa akan dijadikan wilayah pengembangan agropolitan, namun koordinasi masih tidak berjalan dengan baik dikarenakan masyarakat hanya dilibatkan di awal saja, sehingga masyarakat Rubaru tidak setuju akan pembangunan sarana yang berupa pembangunan pasar agropolitan. Sedangkan menurut pendapat yang disampaikan oleh James D.Thompson dalam Widyaiswara (2014:33) Peran koordinator dalam hal ini adalah berupaya 
membuat struktur dan memfasilitasi transaksi antar bagian yang saling bergantung. Terciptanya koordinasi yang baik antar unit atau departemen dapat meminimalisir terjadinya kesalahan dan konflik sehingga proses kegiatan dapat berjalan dengan efektif.

Koordinasi perencanaan wilayah agropolitan terkait penetapan fasilitas yang diberikan pemerintah yaitu pasar agropolitan masih mengalami kendala yaitu dari masyarakat Kecamatan Rubaru yang tidak setujua dengan lokasi pasar agropolitan dan juga dari segi pendanaan yang kurang maksimal, sejalan dengan pendapat Riyadi dan Bratakusumah (2004:15) mengemukakan bahwa ada beberapa faktor yang dapat menjadi kendala dalam perencanaan wilayah, yaitu (1) faktor lingkungan yang terdiri dari aspek sosial, budaya, dan ekonomi, (2) faktor sumber daya manusia, (3) faktor sistem yang digunakan, (4) faktor pendanaan.

Kendala-kendala di wilayah pengembangan agropolitan di Kabupaten Sumenep tersebut dikarenakan lokasi pembangunan pasar agropolitan yang lokasinya yang sempit dan sering terjadi kemacetan, maka dari adanya kendala tersebut sangat dibutuhkan peningkatan koordinasi dan koordinator untuk memecahkan masalah yang ada. Sebagaimana yang dikatakan oleh (Sutarto, 2006:152) bahwasannya peningkatan koordinasi dapat dilakukan dengan mengangkat koordinator usaha dalam menyelaraskan antar bagian dalam organisasi maupun antar unit kerja, dengan adanya seorang koordinator, apabila ada suatu masalah maka dapat diselesaikan dengan baik dan cepat oleh seorang koordinator atau dapat berupa satuan organisasi.

Koordinasi penetapan wilayah agropolitan merupakan hal yang perlu untuk dilakukan karena Kecamatan Rubaru memang memiliki potensi yang cukup besar di sektor pertanian tetapi disadari sepenuhnya bahwa potensi yang besar ini belum tergarap secara optimal. Maka dari itu menjadi sebuah tanggungjawab bagi pemerintah khususnya Bappeda untuk terus melakukan koordinasi dan hubungan kerja dengan instansi terkait serta masyarakat karena mereka merupakan elemen yang berpengaruh terhadap berhasilnya pengembangan wilayah yang telah direncanakan. Sebagaimana pendapat Hasibuan (2011:90) bahwa koordinasi dapat tercapai sebaik-baiknya dengan melakukan hubungan kerja yang efektif. Hubungan kerja adalah bentuk administrasi yang membantu tercapainya koordinasi. Oleh karena itu dikatakan bahwa hasil akhir daripada komunikasi (hubungan kerja) adalah tercapainya koordinasi dengan cara yang berhasil 
guna dan berdaya guna (efektif dan efisien).

\section{Kesimpulan}

Berdasarkan hasil penelitian, analisa penelitian dan pembahasan yang penulis lakukan dapat diketahui bahwasannya pemerintah yaitu Bappeda telah berperan sebagai koordinator pengembangan wilayah agropolitan dalam pembangunan ekonomi masyarakat. Adapun koordinasi tersebut telah sesuai sebagaimana fokus dalam kajian teori oleh Sjafrizal 2015 yakni tentang bentuk perencanaan melalui pendekatan koordinasi. Berikut penulis paparkan mengenai uraian bentuk perencanaan melalui pendekatan koordinasi berdasarkan fokus kajian tersebut.

1) Koordinasi Perencanaan Makro yang pertama dilakukan Bappeda dengan membentuk tim pokja koordinator pengembangan wilayah agropolitan terlebih dahulu yang dimana Bappeda menjadi ketua tim koordinator, kedua adanya pengembangan kelembagaan masyarakat melalui pemberdayaan kelompok tani, gabungan kelompok tani, yang ketiga mengalokasikan anggaran dalam rangka mendukung wilayah agropolitan yaitu antara lain untuk mengembangkan sarana dan prasarananya serta fasilitas penduduk lainnya. Kemudian mengoptimalkan realisasi kegiatan program pengembangan wilayah agropolitan, merubah pengelolahan lahan pertanian yang semula bersifat tradisional menjadi lebih modern, efektif dan tepat guna. namun dalam koordinasi perencanaannya belum berjalan secara baik, ini terbukti bahwa kurangnya kerjasama dan konsistensi antar instansi terkait serta warga yang kurang dilibatkan dalam hal perencanaan wilayah agropolitan ini, mereka hanya dilibatkan dalam satu kali pertemuan saja dan itu hanya di awal saja, kemudian pendanaan yang tersedia kurang maksimal untuk membiayai pengembangan wilayah agropolitan.

2) Perencanaan Sektoral yang dikoordinasikan Bappeda yaitu dengan Dinas Pertanian Tanaman Pangan Hortikultura Dan Perkebunan, Dinas Koperasi Dan Usaha Mikro Serta Dinas Perindustrian Dan Perdagangan, dan masyarakat GAPOKTAN. Dinas Perindustrian Dan Perdagangan mendapatkan tugas mengoptimalkan industri pertanian dan memberikan bantuan peralatan dan permodalan 
untuk petani dan juga pengadaan alat-alat modern agar mempermudah petani dalam mengolah tanaman serta membangun pasar agropolitan, selanjutnya Dinas Pertanian Tanaman Pangan Hortikultura Dan Perkebunan mendapatkan pembagian tugas memberikan informasi benih terbaru serta harga yang terjangkau, pengoptimalan kios untuk penyediaan benih tanaman, mendirikan balai benih di wilayah agropolitan, dan melakukan sosialisasi peningkatan kemampuan petani dalam memproduksi benih tanaman/bibit yang berkwalitas, kemudian Dinas Koperasi dan Usaha Mikro mendapatkan tugas menyediakan benih tanaman pada koperasi unit desa (KUD). Namun hingga saat ini koordinasi perencanaan masih belum berjalan maksimal dan masih berada di taraf $40 \%$, hal ini disebabkan kurangnya komitmen antar tim pokja dengan instansi terkait dan masyarakat terhadap pengembangan wilayah agropolitan.

3) Perencanaan Regional yang dilakukan oleh Pemerintah ialah melihat lokasinya terlebih dahulu dari topografinya, potensinya, hasil pertaniannya kemudian sarana pra sarana lokasinya dan kemudian dilakukan koordinasi antar tim pokja. Namun dari koordinasi tersebut masih terdapat kendala-kendala dalam penetapan wilayah pengembangan agropolitan yang salah satunya yaitu masyarakat tidak dilibatkan dalam perencanaan pembangunan pasar agropolitan sehingga lokasi pasar agropolitan tidak disetujui masyarakat karena sempit.

\section{DAFTAR PUSTAKA}

Adisasmita Rahardjo. 2013. Teori-Teori Pembangunan Ekonomi.

Yogyakarta: Graha Ilmu

Ahmad, Jalaluddin. 2015. Metode Penelitian Administrasi Publik (Teori dan Aplikasi). Yogyakarta: Gava Media

Greenberg, J. And Robert A. Baron. 2003. Perilaku Dalam Organisasi, Jakarta: PT Bumi Aksara.

Handayaningrat. 2006. Pengantar Studi Ilmu Administrasi dan Manajemen, Jakarta: Gunung Agung

Hasibuan Malayu S.P. 2017. Manajemen Dasar, Pengertian, Dan Masalah. Jakarta: PT Bumi Aksara

Himawan, Muammar. 2014. Pokok Pokok Organisasi Modern. Jakarta: Bina Ilmu 
Inu Kencana Syafiie. 2002. Sistem Pemerintahan Indonesia (Edisi Revisi). Jakarta: Rineka Cipta

Jhingan M.L, 2014. Ekonomi Pembangunan Dan Perencanaan.

Jakarta: PT Raja Grafindo Persada

Moleong, Lexy. 2014. Metodologi Penelitian Kualitatif. Bandung: PT Remaja Rosdakarya

Perdana, Iwan. 2014. Metode Penyusunan Skripsi. Malang: Intimedia

Rustiadi Ernan, dkk, 2011. Perencanaan dan Pengembangan Wilayah. Jakarta: Ed. Andrea Emma Pravitasari, Crestpent Press dan Yayasan Pustaka Obor

Siswanto, Bejo. 2011. Manajemen

Tenaga Kerja Indonesia

Pendekatan Administratif dan

Operasional. Jakarta: Bumi

Aksara

Sjafrizal. 2015. Perencanaan

Pembangunan Daerah Dalam Era

Otonomi.

Jakarta: PT Raja Grafindo Persada

Sugiyono. 2014. Metode Penelitian

Pendidikan (Pendekatan

Kuantitatif, Kualitatif, dan $R \& D$ ).

Bandung: Alfabeta

Suryanto, Bagong dan Sutinah. 2011. Metode Penelitian Sosial Berbagai Alternatif Pendekatan. Jakarta: Kencana
Wibisono, Dermawan. 2012. Manajemen Kinerja Korporasi dan Organisasi. Erlangga

Widodo, Tri. 2006. Perencanaan Pembangunan. Aplikasi Komputer (Era Otonomi Daerah). Yogyakarta: UUP STIM YKPN

Widyaiswara. 2007. Analisis Pengaruh Disiplin dan. Koordinasi Kerja terhadap Kinerja Organisasi. Jakarta: PT Raja Grafindo Persada

Wursanto. 2005. Dasar-Dasar Ilmu Organisasi. Yogyakarta: CV Andi Offset

Peraturan Pemerintah Dalam Negeri No 86 Tahun 2017.

Undang-Undang No. 26 Tahun 2007.

"BPS Kabupaten Sumenep", dalam situs https://sumenepkab.bps.go.id/ (Di akses pada 17 November 2018)

"Agropolitan dan Minapolitan Jawa Timur", dalam situs http://agropolitan.jatimprov.go.id/ (Di akses pada 18 November 2018)

"Pembangunan Pasar Agropolitan Diprotes Warga", dalam situs https://penamadura.com/ (Di akses pada 19 November 2018)

"Portal Epublikasi Pertanian", dalam situs http://epublikasi.pertanian.go.id (Di akses pada 03 Desember 2018)

"Perencanaan Menurut Dimensi Pendekatan dan Koordinasi", dalam situs https://www.bappenas.go.id/ (Di akses pada 10 Desember 2018) 